\title{
Information Literacy from the Trenches: How Do Humanities and Social Science Majors Conduct Academic Research?
}

\author{
Alison J. Head
}

This article examines the ways in which students majoring in humanities and social sciences conceptualize and operationalize course-related research. Findings are presented from an information-seeking behavior study with data collected from student discussion groups, a student survey, and a content analysis of professors' research assignment handouts. Results indicate that students first use course readings and library resources for academic research and then rely on public Internet sites later in their research process. Students adopt a hybrid approach to course-related research. A majority of students in this study leveraged both human and computer-mediated resources to compensate for their lack of information literacy. In particular, students faced problems with determining information needs for assignments, selecting and critically evaluating resources, and gauging professors' expectations for quality research.

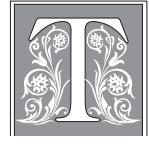

he ubiquitous topic of information literacy has perplexed many a college librarian, professor, and administrator. In simple terms, information literacy consists of the competencies students must have in order to locate, retrieve, evaluate, select, and use information. These competencies are developed over time and are essential for lifelong learning. ${ }^{1}$

However, little is simple or straightforward about information literacy. ${ }^{2}$ Upon closer scrutiny and practical implementation, questions inevitably arise about operationalizing information literacy initiatives: How should competencies be woven into the fabric of college curricula? How and by whom should students' competencies be measured? What should be done for students who lack information literacy skills?

The burgeoning availability of information technology and the proliferation of digital information resources have thrown these and other questions into high relief. In the past few years, library research literature has focused on the imperative need for codifying informa-

Alison J. Head is the Roy and Patricia Disney Visiting Professor in New Media in the Communication Department at Saint Mary's College of California (SMC) and Co-Director of Project Information Literacy; e-mail: ajhead1@gmail.com. The author gratefully acknowledges the assistance of this study's research associates: Micheline Sabatte, Neeley Silberman, and Sarah Vital. This study was sponsored with support from the SMC Academic Library and Communication Department. 
tion literacy initiatives, standards, and measures. These efforts have occurred at a time when students are more dependent than ever on search engines and public Internet sites for academic research. Yet, as all of these changes have occurred, one question about information literacy has rarely been addressed in the library literature. ${ }^{3}$ How do students conducting academic research actually put their information literacy competencies into daily practice-regardless of how well they may (or may not) measure up to the information literacy competency standards set by campus authorities?

This study views the topic of information literacy through the lens of the college students' research experience. ${ }^{4}$ Findings are reported from a 2007 study undertaken by a research team of faculty and librarians at a small, liberal arts college. The study focused on how undergraduates majoring in humanities and social sciences conceptualize and operationalize research tasks for course-related assignments. ${ }^{5}$ The primary contribution of this research is to provide an inside view of the student research process, which some faculty and librarians may have, unknowingly or inaccurately, assumed is similar to their own. ${ }^{6}$

\section{Review of Literature}

In 1989, the same year Timothy Berners-Lee invented the World Wide Web, the Association of College and Research Libraries (ACRL) defined information literacy as "a set of abilities requiring individuals to recognize when information is needed and have the ability to locate, evaluate, and use effectively the needed information." ${ }^{7}$ Eleven years later, firmly in the digital age, ACRL released a set of information literacy standards, performance indicators, and outcomes for use in higher education. ${ }^{8}$ ACRL's report was spurred by needs arising from the pleth-

ora of new information technologies and online information sources and a concern about the "escalating complexity" of the information retrieval environment. ${ }^{9}$ Table 1 shows the six general competencies of the information-literate individual, as described by ACRL in 2000. ${ }^{10}$

According to the ACRL report, higher education institutions have a central function in sharpening students' informationseeking and critical-thinking skills and in training students to "learn how to learn" within the campus setting and elsewhere for the rest of their lives. ${ }^{11}$ Through collaborative efforts, faculty establish the context for learning and exploration. Librarians evaluate resources and provide services and instruction. Administrators plan for sustainability of information literacy initiatives. In particular, the campus library is the linchpin in advancing students' information literacy competencies, according to the ACRL document.

\section{Information Literacy Levels Lag}

Despite ACRL's efforts, the information literacy competency levels for a large majority of students are low. At last count, a large-scale study by the Educational 
Testing Service (ETS) in 2006 reported test takers in a sample of high school seniors and college students "sorely lacked in the skills needed to retrieve, analyze, and communicate information that is available online" and "only 13 percent could be considered information literate." 12

One frequent explanation for the decline in information literacy levels is students' growing reliance on the Internet for academic research, rather than libraries, where information literacy skills are often nurtured. ${ }^{13}$ In fact, a 2002 Pew Internet and American Life Project report found nearly three-quarters (73\%) of college students reported using the Internet more than the campus library for research. ${ }^{14} \mathrm{~A}$ growing number of recent studies in the library literature have since found that a vast majority of students conducting academic research turn to public sites on the Internet first..$^{15}$ Further, students turn to the Internet instead of turning to library-funded resources, many of which are also accessible online.

Some authors have claimed that college library usage may be flagging. One theory holds that a majority of college students are unaware of the plethora of library resources available to them and are unskilled in accessing library materials. In "Information Illiterate or Lazy: How College Students Use the Web for Research," Christen Thompson reports that students use the Internet (specifically, commercial search engines such as Google) as the first step in course-related research to bypass grappling with understanding the library's operational complexities. ${ }^{16}$ In "Information-Seeking Behavior in Generation Y Students: Motivation, Critical Thinking, and Learning Theory," Angela Weiler applies learning theory to further claim students have an increased use of the Internet (along with television), because of the overall decrease in cognitive skills, which are necessary for book-learning. ${ }^{17}$

\section{How Students View the Research Process}

Few articles in the library literature have investigated the undergraduate research process from the student's viewpoint. One study by Anne F. Pierce, "Information-Seeking Behavior in Generation Y Students," looks at how high school students use the Internet to conduct research for schoolwork. ${ }^{18}$ Pierce finds students considered themselves competent researchers, even though most proved to be unskilled in unearthing research materials from the Internet. ${ }^{19}$

In "Desperately Seeking Citations: Uncovering Faculty Assumptions about the Undergraduate Research Process," Gloria Lecke lends further insight into the college student's research process. Her qualitative analysis contrasts university faculty research models with students' models. She claims that students bring an entirely different mental model to the research process than do faculty. ${ }^{20}$

According to Leckie, faculty in the humanities and social sciences disciplines tend to use an "expert researcher" model. Faculty conceptualize the research process, honed through years of acculturation, detailed knowledge of a discipline, an awareness of the "invisible college" of scholars contributing to a body of knowledge, and a firm understanding of the nonlinear nature of research. ${ }^{21}$ By contrast, undergraduates are untrained in any expert model of research, employing a "coping strategy" instead, especially when conducting course-related research.

Leckie writes that, in general, undergraduates have little context for understanding the scholarly research process: "For the most part, students in the humanities and social sciences tend to be limited in their exposure to scholarly research (usually only through a textbook or lecture account), have little to no knowledge of ongoing scholarly research that occurs within discipline, and have a fixed level of cognitive development in which they find ambiguity and non-linearity [as] threatening." 22

In sum, there is little question, as one author writes, that interest in information literacy is "thriving" and "in library 
literature, information literacy is consistently among the most important and most discussed topics, and it has been so for nearly two decades." ${ }^{23}$ However, at the same time, even with a copious amount of research dedicated to the topic of information literacy and the enactment of information literacy initiatives and the hiring of information literacy librarians on individual campuses, the battle continues. Students still lack information competencies at the same time campus library usage is allegedly waning and as the use of the Internet for research increases.

\section{Research Questions}

This study uses the lens of the student research experience to gain deeper insights into information literacy. The goals of this study are twofold: (1) to understand what differences may exist between professors and students about what they think the research process entails, and (2) to explore how student information literacy competencies may be improved through professors' and librarians' efforts.

Accordingly, three research questions are posed:

1. How do students, majoring in lower-division humanities or social sciences courses, conceptualize the course-related task of research and operationalize these concepts into research activities for course-related work?

2. What information resources do students majoring in humanities and social sciences use to carry out course-related research?

3. What challenges, barriers, and obstacles exist for students conducting research for humanities and social sciences courses?

\section{Methodology}

The research study was conducted during January to May 2007 at Saint Mary's College of California (SMC), a small Catholic and Lasallian Christian Brothers' liberal arts institution in Moraga. The college has an enrollment of 2,489 undergraduates with a 12:1 student-to-teacher ratio. ${ }^{24}$
SMC's Instructional Research Board (IRB) approved a comprehensive research protocol for the study on January 25, 2007.

Data were collected in two primary areas:

1. Information-seeking behavior data (from discussion groups and a student survey) about how students conceptualize and operationalize academic research for humanities and social science courses.

2. Content analysis data from the research assignment handouts professors distributed to students in humanities and social science courses.

Upper-division students majoring in humanities and social sciences constituted the study's sample. This study population was selected because juniors and seniors were assumed to be more familiar with the secondary research process than were their lower-division counterparts. Unlike the laboratory research many science majors are required to conduct, humanities and social science majors are more likely to be acquainted with secondary research than with primary research.

\section{Student Discussion Groups}

Two one-and-half-hour informal discussion sessions were conducted on February 27 and March 1 . The total sample for the discussion groups was 13 participants. Of the total, six were male and seven were female. The sample consisted of majors from Communication, Politics, Economics, Liberal Arts, Health, and Psychology.

The goal of the sessions was to collect qualitative data about how students conduct research for papers assigned in humanities and social science courses. In particular, there was discussion among participants about their research habits, behaviors, experiences, and the obstacles they encounter in the research process.

\section{Student Survey}

The student survey was administered between March 6 and March 23 in 20 classes to juniors and seniors majoring in humanities or social sciences. The survey 


\begin{tabular}{|l|c|}
\hline \multicolumn{2}{|c|}{ TABLE 2 } \\
Survey Sample Segmentation \\
\hline \hline Major & $\begin{array}{c}\text { Percentage } \\
\text { (and Count) }\end{array}$ \\
\hline Anthropology/Sociology & $6 \%(10)$ \\
\hline Classical Languages & $1 \%(1)$ \\
\hline Communication & $26 \%(46)$ \\
\hline Economics & $4 \%(2)$ \\
\hline English and Drama & $9 \%(16)$ \\
\hline History & $6 \%(11)$ \\
\hline Kinesiology & $14 \%(25)$ \\
\hline Liberal and Civic Studies & $5 \%(9)$ \\
\hline Performing Arts & $1 \%(1)$ \\
\hline Politics & $12 \%(21)$ \\
\hline Psychology & $9 \%(16)$ \\
\hline Religious Studies & $1 \%(1)$ \\
\hline Other (double majors) & $10 \%(17)$ \\
\hline Total Sample & $\mathbf{1 0 0 \% ( n = 1 7 8 )}$ \\
\hline Source: Data from Student Survey, $\mathrm{n}=178$ \\
\hline
\end{tabular}

and editing research papers, and (6) the major concerns with working on research projects. (See Appendix A for a copy of the survey.)

\section{Content Analysis of Professors' Handouts}

To provide additional data on the student research process, a quantitative content analysis of research assignment handouts used by professors was conducted from January 29 through February 17 . Thirty handouts detailing student research assignments in a humanities or social sciences course were analyzed. Research handouts were collected from professors who had distributed them to students in humanities social science classes in the last two years. The sample was derived from courses in a variety of departments on campus, including Anthropology/Sociology, Art, Communication, Economics, English, History, Kinesiology, Politics, Psychology, Religion, and Women's Studies.

The goal of the content analysis was twofold: (1) to find out what professors assign, and (2) to find out the amount of

sample was 178 students. The sample was 72 percent female and 28 percent male. ${ }^{25}$ One respondent in four was a Communication major. Table 2 shows a breakdown of the survey sample by major.

The 15-question survey was designed to collect quantitative data about how upper division humanities and social sciences majors conceptualize and carry out course-related research. The survey questions were informed by qualitative themes gathered from the two discussion groups held earlier during this research project.

In particular, the survey asked respondents to answer questions about: (1) the steps they took during the research process, (2) the perceived helpfulness of the campus library, (3) the perceived helpfulness of professors' coaching techniques on research assignments, (4) the problems experienced during the research process, (5) the time spent researching, writing, guidance professors offer students about how to carry out their research, how to evaluate and cite resources, and how to assemble and prepare the final paper.

\section{Coding Method and Reliability}

During the analysis phase, two coders systematically identified the manifest and latent properties of wording and phrasing that appeared in thirty randomly assigned research assignments. Before the official coding process began, the codebook was pilot tested with a sample of three handouts and accordingly rewritten.

Each coder read twenty handouts and assigned a designated numerical code for the occurrence of a certain property (for instance, "use of a reference librarian is recommended as a resource to consult"). Coders evaluated ten handouts on their own, and another ten of the same handouts each, to measure "intercoder reliability," or the consistency between 


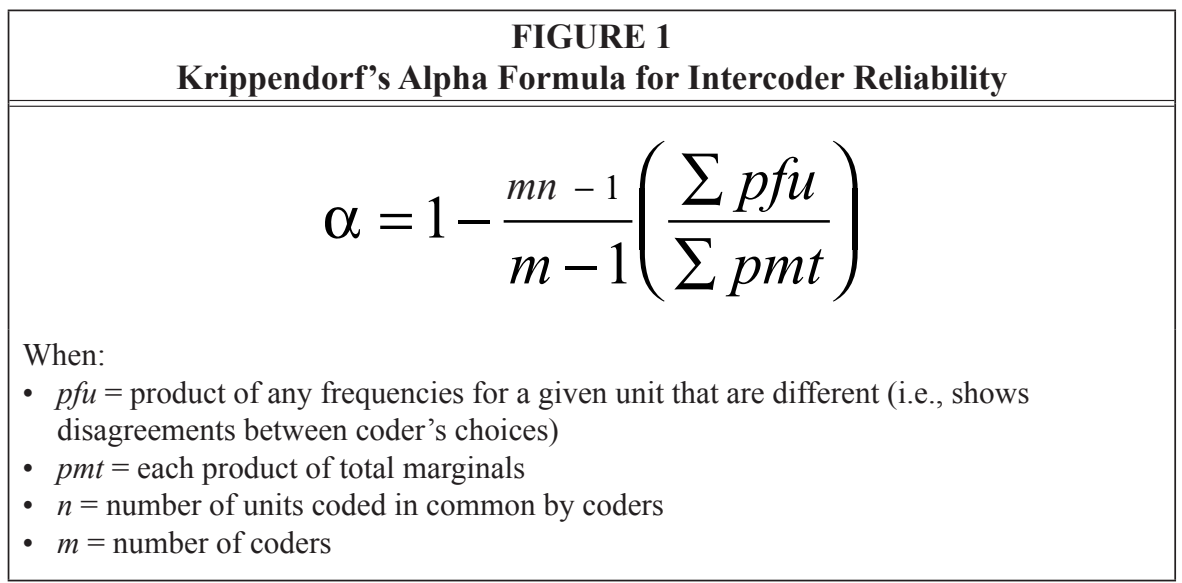

each coder's individual coding decisions. A current version of the SPSS statistical package (Version 14) and the statistic known as Krippendorf's Alpha were used to test our intercoder reliability and to measure the degree of variation between the two coders' coding decisions. Krippendorf's Alpha (Krippendorf's $\alpha$ ) is considered the most rigorous test of intercoder reliability. The measure takes into account chance agreement among content analysis coders and adjusts for nominal, ordinal, interval, and ratio variables. Figure 1 shows the mathematical formula for determining Krippendorf's Alpha. ${ }^{26}$
There is no "acceptable" standard for intercoder reliability. However, communication research scholars have argued that a coefficient of 90 or higher is "highly acceptable," and even .80 is acceptable in most situations. ${ }^{27}$ Overall, the intercoder reliability for all 17 properties coded in this study was .928176 . This means that there was nearly a 93 percent degree of reliability coding between the coders' individual decisions - a highly acceptable rate.

\section{Results}

Humanities and social sciences majors live in a world of four- to six-page argument papers, literature reviews, and

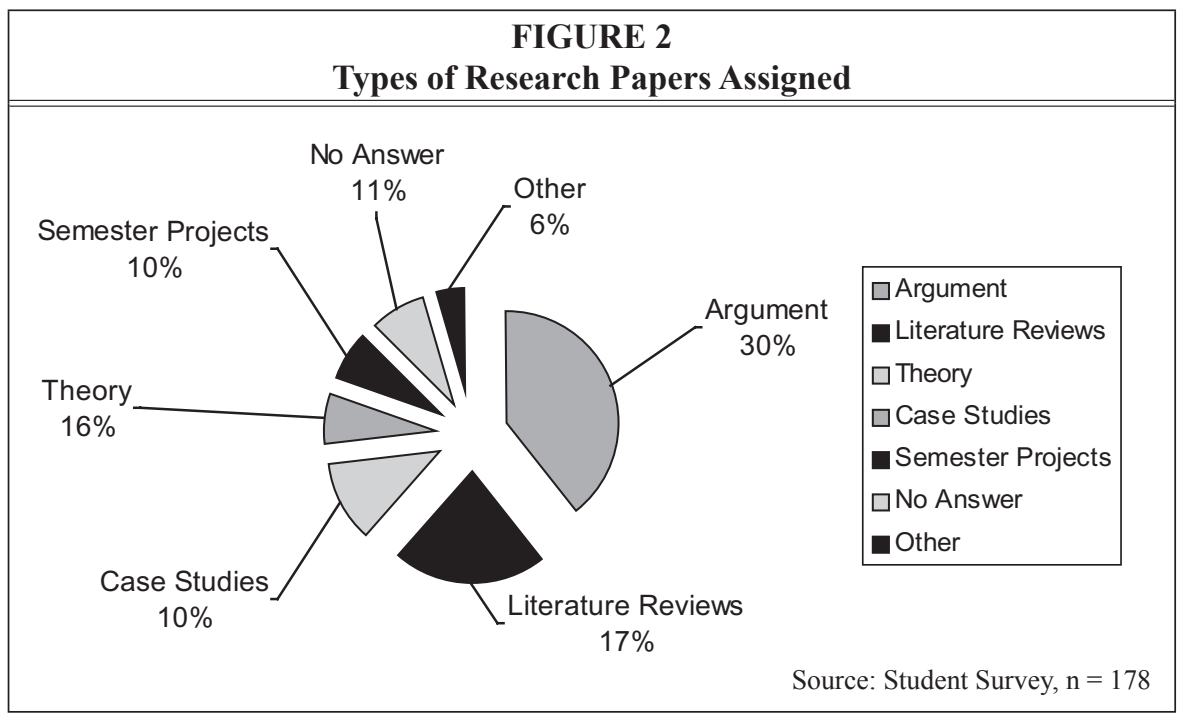


theory papers, according to the survey data. The so-called argument paper is the signature assignment for majors. This type of assignment requires students to conduct scholarly research about a topic and present clear and sound evidence that advances a proposition or proposal. Figure 2 shows a breakdown of the types of research papers assigned to students.

\section{How Students Conceptualize Course- Related Research}

Most of the participants in the discussion groups claimed to understand the basics of writing research papers. They knew, for instance, that these papers required critical analyses and did not call on students to explore and articulate their personal feelings. In many cases, participants reported they were free to choose and write on any topic in their courses, as long as their papers met the professor's expectations and the course objectives.

Students frequently work alone on assignments and are given some freedom in choosing the topic they would like to explore. As a result, there is a wide swath of "real world" topics that students select for their argument papers. The discussion group participants recalled writing about, for example, working mothers and feminism, Hurricane Katrina's impact on New Orleans, college athletes and self-esteem, the impact of iPods on human isolation, teen suicide, divorce, Satanism, and the gay rights movement.

Pressures to be original and creative were the first concerns the majority of the participants discussed at length in both sessions. One participant found it difficult to be creative from class to class and constantly having "to say something new." More than a third of the other participants admitted having struggled to narrow down a topic and keeping it interesting while conducting research.

In both sessions, students discussed their struggle with limiting the scope of a research topic and dealing with the inevitable information overload that accompanies new forms of digital media. To offset these problems, some participants turned to the Wikipedia community encyclopedia Web site to obtain background about a topic. Yet, at the same time, there was consensus about Wikipedia's unreliability, especially since anyone can contribute an entry to the site. While students admittedly used Wikipedia with trepidation, none of the participants found other community sites, such as blogs (in other words, online diaries), to be useful research resources. Most doubted that blogs would be acceptable sources for college-level research work and would not even think about using them.

\section{How Students Operationalize Research Tasks}

According to the survey data, most students start the research process by accessing nearby and convenient resources. The largest percentage of students surveyed (40\%) reported that the first step they took during the research process was to consult the course textbook or other assigned

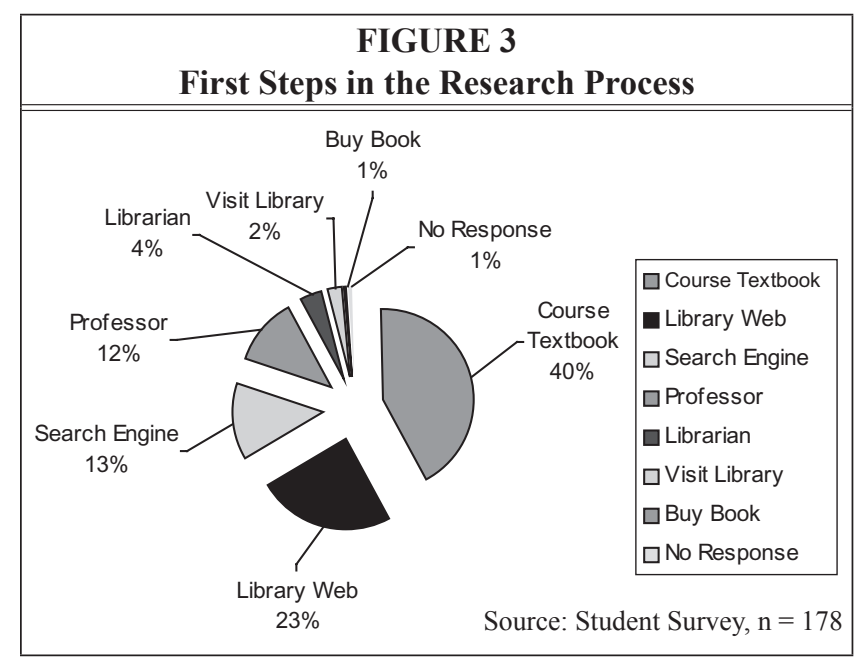


class readings. ${ }^{28}$ Fewer students (23\%) reported using the library Web site to access the databases, search engines such as Google and Yahoo! (13\%), and talking to a professor $(12 \%)$. Figure 3 shows a breakdown of the students' first step in conducting research.

The second step students took varied. Some students (24\%) accessed online resources on the campus library's Web site. Others $(20 \%)$ used a search engine such as Google or Yahoo! Smaller percentages of students consulted a print or online encyclopedia such as Britannica $(5 \%)$, or an online community encyclopedia such as Wikipedia (4\%).

\section{Helpfulness of Professors}

According to students surveyed, one key factor of their success (receiving a good grade) was when a research assignment included some "high touch" features (that is, human-mediated), such as oneon-one coaching sessions, instead of only "high tech" ones (in other words, computer-mediated), such as online resources. To meet their "high touch" needs, students went to professors and librarians for help.

Most of the students $(72 \%)$ in the survey agreed with the statement that one-on-one sessions were helpful, especially when professors offered individual coaching on an assignment. Students also saw the option of writing and rewriting drafts as a factor in their success. Over half of the surveyed students (82\%) agreed that drafting some sections for professors' review and comment before submitting the final paper was helpful in raising their grade for the assignment.

\section{Helpfulness of Libraries}

There was a strong consensus among discussion group participants about the helpfulness of the campus library. In those qualitative discussions, more than two thirds of the participants (69\%) told us they consulted reference librarians when they needed to narrow down a topic; the same percentage of respondents also said they relied on the online databases posted on the library's Web site (examples: Link+, PsycInfo, and Expanded Academic Index).

The survey data substantiated claims about the perceived helpfulness of libraries. Over two thirds of the student survey sample (68\%) either "somewhat" or "strongly" agreed with the statement that the campus reference librarians were helpful when they needed to write a fourto six-page research paper. Likewise, over three fourths of the surveyed students agreed that the online databases available through the campus Web site were helpful to them (88\%). But only slightly more than half of the surveyed students (53\%) found bibliographic instruction or in-class "library talks" as much help. Figure 4 shows a breakdown of what library resources students found helpful when researching a four- to six-page paper.

\section{Challenges and Obstacles: Student Limitations \\ The majority of students $(61 \%)$ in the discussion group and survey}


samples had an overall grade point average (GPA) that was between 2.7 and 3.3 (B to $\mathrm{B}+)$. Despite their relatively high grade point averages, the research process for a variety of reasons frequently frustrated students. According to the survey data, the typical student struggles with research assignments because of: (1) his or her own tendency to procrastinate (73\%), (2) his or her feelings of being overwhelmed by all the information that is "out there" (60\%), and (3) his or her inability to narrow down a topic and make it manageable $(59 \%) .{ }^{29}$ In combination, these data support an overall finding: Most students are challenged by tasks requiring specific information literacy competencies, such as retrieving, evaluating, selecting, and using information.

For many students, the research process is a barely "tolerable task," usually delayed until a few days before a dropdead due date. All but one of the participants in the discussion group described themselves as procrastinators. As with any procrastinator, time is always of the essence; and, for students who procrastinate on research assignments, the situation is no different.

Students surveyed only spent one to five hours (77\%) conducting research and collecting resources. After completing the research, most students spent one to five more hours (72\%) writing and editing a four- to six-page research paper. When working on assignments, students are primarily concerned with the grade they will receive (44\%) and less concerned with getting the assignment finished (20\%) and being creative (10\%).

\section{Challenges and Obstacles: Research Assignment Handouts}

Students in the discussion groups reported that one of their most serious obstacles is understanding professors' expectations for assignments. Trying to figure out exactly what each professor expected caused the most frustration for twelve out of thirteen discussion group participants. The survey substantiated these results: Nearly half of the survey sample strongly agreed with the statement that a lack of information from the assigning professor stymied them the most, sometimes keeping them from beginning an assignment at all $(48 \%)$.

The content analysis of the handouts professors distributed for research assignments lends further insight into students' inability to know what their professors expected. From a systematic content analysis, the data show a lack of detail and guidance in many research assignment handouts. ${ }^{30}$ As a whole, the handouts offered little direction about: (1) plotting the course for research, (2) crafting a quality paper, and (3) preparing a paper that adheres to a grading rubric of some kind.

\begin{tabular}{|l|c|c|c|c|c|}
\hline \multicolumn{7}{|c|}{ TABLE 3 } \\
\hline & Resources that Professors Do and Do Not Recommend \\
\hline \hline & - & $17 \%$ & - & - & $83 \%$ \\
\hline Reference librarian & 0 & 5 & 0 & 0 & 25 \\
\hline $\begin{array}{l}\text { Online resources } \\
\text { from library site }\end{array}$ & $17 \%$ & $10 \%$ & - & - & $73 \%$ \\
\hline $\begin{array}{l}\text { In-library resources } \\
\text { (off the shelves and } \\
\text { on-site) }\end{array}$ & 5 & 3 & 0 & 0 & 22 \\
\hline $\begin{array}{l}\text { Resources found on } \\
\text { the Web }\end{array}$ & $3 \%$ & $13 \%$ & $3 \%$ & - & $70 \%$ \\
\hline Source: Content Analysis, $\mathrm{n}=30$ & 1 & 1 & 1 & 0 & 21 \\
\hline
\end{tabular}


Few of the handouts analyzed mentioned where students were to look for research resources. In particular, most handouts had no information about whether or not to use resources such as the Web $(87 \%)$, a librarian $(83 \%)$, online resources from the school's library site $(73 \%)$, or library resources pulled right off the shelf $(70 \%)$. Table 3 shows a breakdown of research guidance professors offered in research handouts that were analyzed.

When provided, the guidelines for crafting a quality research paper were often terse and formulaic. Only about a third of the handouts $(30 \%)$ made some reference to plagiarism and the ethical use of information. Among those that did, most handouts only referenced the college's Honor Code and advised students to consult the code on their own for more information. Last, grading criteria - many students' major concern when working on a research assignment-were sorely underrepresented. Only four out of thirty $(16 \%)$ of the handouts included either a grading rubric or a point breakdown for an assignment. Table 4 shows a breakdown of guidelines professors included in research handouts for crafting quality papers.

\section{Discussion}

There is an ongoing discussion in the library literature, claiming students have a paucity of information literacy compe- tencies and are less likely than ever to take advantage of the campus library. At the same time, students' usage of pubic Internet sites for academic research is reportedly on the rise.

Data from this study substantiated some-but not all-of these claims. In contrast to some previous claims, this study found that students actually do use the campus library. Students also found a number of library resources to be helpful, including reference librarians and the databases from the library Web site. In the survey, a majority of students reported not being as reliant on search engines, as other research studies have suggested for beginning their academic research; only one in thirteen of the students in the survey reported having used Yahoo! or Google in the initial stage of their academic research.

However, this study did find students lacking in information literacy competencies, especially as detailed in the ACRL standards for higher education. In particular, students in this study reported that they struggled to: (1) determine the nature and extent of information needed, ${ }^{31}$ and (2) evaluate information and its sources critically to incorporate selected information into their knowledge base and value system. ${ }^{32}$

The following snapshot of the student research experience emerged from this study's findings, based on students' own

\begin{tabular}{|l|c|c|}
\hline \multicolumn{2}{|c|}{ TABLE 4 } \\
\hline \multicolumn{2}{|c|}{ How Should a Quality Paper Be Crafted? } \\
\hline \hline \multicolumn{2}{|c|}{ Yes } & No \\
\hline Includes information on plagiarism and ethical use of information (i.e., & $30 \%$ & $70 \%$ \\
defines plagiarism, cites SMC Honor Code). & 9 & 21 \\
\hline Includes information on proper citation style. & $43 \%$ & $57 \%$ \\
& 13 & 17 \\
\hline Includes information on reviewing authority of materials. & $20 \%$ & $80 \%$ \\
\hline Includes information on reviewing currency of materials. & 6 & 24 \\
\hline Includes information about using spell-check. & $17 \%$ & $83 \%$ \\
& 5 & 25 \\
\hline Source: Content Analysis, n=30 & $7 \%$ & $93 \%$ \\
\hline
\end{tabular}


accounts, experiences, and opinions about conducting academic research:

1. Most students are baffled by college-level research, especially when they must begin the process and define their information needs. As a result, students face a variety of obstacles, including their own procrastination.

2. Other challenges relate to accessing and critically evaluating quality resources, especially what students describe as their own inability to narrow down topics and make them manageable. Students also have a tendency to become overwhelmed by the plethora of available resources, including many from the Web, that are available to them.

3. The most significant obstacle for students, however, is figuring out what each research assignment entails, especially when they are writing different papers for more than one professor.

\section{A Hybrid Approach to Research}

Despite their information literacy challenges, students in the discussion groups reported using a "tried and true" research strategy for completing humanities and social science research assignments. Students' workaround relied heavily on accessing research materials from the library Web site or course readings. One explanation for this approach is that students considered such sources to have already been vetted and more likely to meet professors' expectations for quality research - standards poorly described in professors' research handouts analyzed in this study. Another explanation for this approach is that students do not know how to find-let alone evaluate-quality research sources on the Internet. Consequently, students were more likely to trust more reliable aggregators for what constituted "scholarly sources" (that is, professors, librarians, and the sources in vendor databases).

From the survey, students also clearly valued individualized training. Training from librarians and professors about how to conduct research and overcome certain problems was helpful. Students were baffled by how to begin assignments, meet the expectations of different professors, and to limit a topic to a manageable scope; Internet searches can do little to mitigate these problems. To a lesser extent, students reported problems with determining the credibility of resources and avoiding plagiarism. One explanation for needing individualized training is that students are trying to close the gap they know exists between their own knowledge of the research process and that of their instructors.

This study found that most students find it difficult to conceptualize and to operationalize course-related research. For many students, course-related research is nearly impossible, despite the convenience and students' assumed reliance on the Internet. Students appear to be particularly limited in their ability to find "good, citable stuff," especially when mining public Internet sites.

These findings suggest that, even though young people may have been exposed to computers since they learned the alphabet and may be avid users of sites like MySpace and YouTube, college-aged students are no more likely to be natural-born researchers and scholars than anyone else. Conducting secondary research remains a formidable task, one that must be learned through instruction and honed with practice - a fact that librarians have known for ages.

\section{Conclusion}

This study is a departure from most of the research literature about the topic of information literacy. By collecting data from students' own accounts, this study found that students are aware of and frustrated by their own problems with selecting and evaluating information. Consequently, a majority of students reported using a hybrid approach to research as a workaround for achieving success in their course assignments.

There are limitations to the study, given the exploratory nature of the work, the size 
of the study population and samples, and the inherent issue of "self report," which is always problematic when a survey method or discussion groups are employed. Further research with a more diverse sample at different institutions (such as public and private universities and community colleges) is essential to generalize these initial findings. Yet findings from this study may be a good basis for accompanying information literacy initiatives already in place on campuses (as long as further research is conducted about individual settings).

To that end, three recommendations are offered to professors and librarians who hope to improve students' information literacy levels:

1. Professors should be more explicit about their expectations when they prepare handouts for research assignments. Handouts need to inform students about the following: (1) how to carry out sec- ondary research, (2) how to craft quality papers, and (3) how students' work will be evaluated. In some institutions, individual departments have begun adopting a single grading rubric that appears on each course syllabus. ${ }^{33}$ A similar approach could be used by instituting or at least recommending a "research rubric" for faculty handouts.

2. Both professors and librarians may want to expand, if at all feasible, the hands-on services and support that are already provided to students. Data from this study showed that students valued one-on-one coaching sessions with these research "experts."

3. Finally, the value of human over computer-mediated services should not be underestimated, especially when it comes to developing practices and initiatives for improving the information literacy competencies of students taking humanities and social science courses.

\section{Appendix A: Student Survey Form}

1. Please start off by telling us a little about you. Are you:

$\square$ Female

Male

2. How old were you on your last birthday?

$\square$ 19-20 years old

21-22 years old

23-25 years old

$\square$ Over 25 years old

3. Are you currently a junior or a senior, according to the Registrar's Office on campus?

$\square$ Junior

$\square$ Senior

4. What was your overall GPA, as of last semester, according to the Registrar's Office on campus?

$\square$ 4.0-3.8 (A)
$\square 3.7-3.4(\mathrm{~A}-)$
$\square 3.3-3.1(\mathrm{~B}+)$
$\square 3.0-2.7(\mathrm{~B})$
$\square 2.6-2.4(\mathrm{~B}-)$
$\square$ 2.3-2.0 (C+)

$\square$ No answer from respondent 
5. What is your major?

Anthropology and Sociology

Art and Art History

Classical Languages

$\square$ Communication

$\square$ Cross-Cultural Studies

$\square$ Economics

$\square$ English and Drama

$\square$ History

$\square$ Kinesiology

Liberal and Civic Studies

$\square$ Modern Languages

$\square$ Performing Arts: Dance, Music, and Theater

$\square$ Philosophy

$\square$ Politics

$\square$ Psychology

$\square$ Religious Studies

Women's Studies

$\square$ If other, including double majors, please specify:

6. As a Humanities or Social Sciences major, what one type of research paper do you write in your classes most frequently? (Please choose one answer only.)

Argument papers about a social issue (e.g., 4-6 pages)

$\square$ Literature reviews

$\square$ Case study analyses

Theory papers (applying a theory covered in class to a topic)

$\square$ Semester-long projects (e.g., thesis)

$\square$ No answer from respondent

$\square$ If other, please specify:

7. What is the first step you take in your own research process for a 4-6-page paper in Humanities or Social Sciences course?

$\square$ Use a textbook or other reading(s) from the class

Talk to the professor outside of class, who assigned the research paper

$\square$ Use a search engine to find resources (e.g., Google, Yahoo!)

U Use an online "community encyclopedia," where anyone can contribute content and post it on the Web (i.e., Wikipedia)

Use an online or print scholarly encyclopedia (e.g., Britannica)

$\square$ Use the online resources available through the SMC Library Web site

Consult a reference librarian in the SMC Library

Visit the SMC Library and see what I can find on the shelf

$\square$ Buy a book(s) that has information I can use

$\square$ No answer from respondent

8. What is the second step you take in your own research process?

$\square$ Use a textbook or other reading(s) from the class

Talk to the professor outside of class, who assigned the research paper

Use a search engine to find resources (e.g., Google, Yahoo!)

U Use an online "community encyclopedia," where anyone can contribute content and post it on the Web (e.g., Wikipedia) 
Use an online or print scholarly encyclopedia (e.g., Britannica)

$\square$ Use the online resources available through the SMC Library Web site

$\square$ Consult a reference librarian in the SMC Library

Visit the SMC Library and see what I can find on the shelf

$\square$ Buy a book(s) that has information I can use

$\square$ If other, please specify:

$\square$ No answer from respondent

9. What is the third step you take in your own research process?

$\square$ Use a textbook or other reading(s) from the class

Talk to the professor outside of class, who assigned the research paper

Use a search engine to find resources (e.g., Google, Yahoo!)

U Use an online "community encyclopedia," where anyone can contribute content and post it on the Web (e.g., Wikipedia)

$\square$ Use an online or print scholarly encyclopedia (e.g., Britannica)

Use the online resources available through the SMC Library Web site

$\square$ Consult a reference librarian in the SMC Library

$\square$ Visit the SMC Library and see what I can find on the shelf

$\square$ Buy a book(s) that has information I can use

$\square$ If other, please specify

$\square$ No answer from respondent

10. What SMC Library resources do you find you helpful when you are conducting research for a 4-6-page research assignment? How much do you agree with each one of the following statements?

\begin{tabular}{|l|l|l|l|l|l|l|}
\hline $\begin{array}{l}\text { SMC reference } \\
\text { librarians are helpful } \\
\text { to me during the } \\
\text { research process }\end{array}$ & $\begin{array}{c}\text { Strongly } \\
\text { Disagree }\end{array}$ & $\begin{array}{c}\text { Somewhat } \\
\text { Disagree }\end{array}$ & $\begin{array}{c}\text { Neither } \\
\text { Agree nor } \\
\text { Disagree }\end{array}$ & $\begin{array}{c}\text { Somewhat } \\
\text { Agree }\end{array}$ & $\begin{array}{c}\text { Strongly } \\
\text { Agree }\end{array}$ & $\begin{array}{c}\text { No Answer } \\
\text { from } \\
\text { Respondent }\end{array}$ \\
\hline $\begin{array}{l}\text { Online databases } \\
\text { available through the } \\
\text { SMC library Web } \\
\text { site are helpful to me } \\
\text { during the research } \\
\text { process }\end{array}$ & & & & & & \\
\hline $\begin{array}{l}\text { Resources that I find } \\
\text { on the shelf in the } \\
\text { library are helpful } \\
\text { to me during the } \\
\text { research process }\end{array}$ & & & & & & \\
\hline $\begin{array}{l}\text { In-class sessions } \\
\text { on how to conduct } \\
\text { research that are } \\
\text { taught by librarians } \\
\text { are helpful to me } \\
\text { during the research } \\
\text { process }\end{array}$ & & & & & & \\
\hline
\end{tabular}


11. How do professors help you do better at completing their research assignments? How much do you agree with each one of the following statements?

\begin{tabular}{|c|c|c|c|c|c|c|}
\hline & $\begin{array}{l}\text { Strongly } \\
\text { Disagree }\end{array}$ & $\begin{array}{c}\text { Somewhat } \\
\text { Disagree }\end{array}$ & $\begin{array}{c}\text { Neither } \\
\text { Agree nor } \\
\text { Disagree }\end{array}$ & $\begin{array}{c}\text { Somewhat } \\
\text { Agree }\end{array}$ & $\begin{array}{c}\text { Strongly } \\
\text { Agree }\end{array}$ & $\begin{array}{l}\text { No Answer } \\
\text { from } \\
\text { Respondent }\end{array}$ \\
\hline $\begin{array}{l}\text { Professors help me } \\
\text { do better on their } \\
\text { research assignments } \\
\text { when they have } \\
\text { separate deadlines } \\
\text { for different parts of } \\
\text { the entire assignment } \\
\text { (e.g., introduction due } \\
\text { first, then body due } \\
\text { later, and so on) }\end{array}$ & & & & & & \\
\hline $\begin{array}{l}\text { Professors help me } \\
\text { do better on their } \\
\text { research assignments } \\
\text { when they let me turn } \\
\text { in drafts that they } \\
\text { comment on so that I } \\
\text { can revise my work }\end{array}$ & & & & & & \\
\hline $\begin{array}{l}\text { Professors help me } \\
\text { do better on their } \\
\text { research assignments } \\
\text { when they have one- } \\
\text { on-one sessions where } \\
\text { they "coach" me } \\
\text { through the research } \\
\text { process and make } \\
\text { suggestions about } \\
\text { how to proceed }\end{array}$ & & & & & & \\
\hline
\end{tabular}

12. Now let's turn to the problems you may have experienced when you are conducting research for Humanities and Social Sciences assignments. How much do you agree or disagree with each of the following statements? I have problems conducting research...

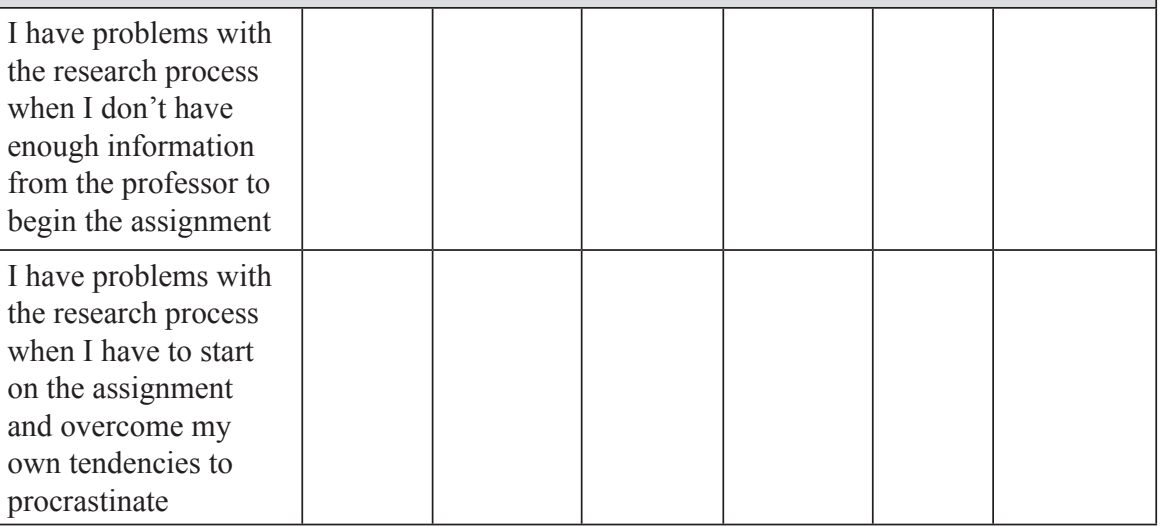




\begin{tabular}{|c|c|c|c|c|c|c|}
\hline & $\begin{array}{l}\text { Strongly } \\
\text { Disagree }\end{array}$ & $\begin{array}{l}\text { Somewhat } \\
\text { Disagree }\end{array}$ & $\begin{array}{c}\text { Neither } \\
\text { Agree } \\
\text { nor } \\
\text { Disagree }\end{array}$ & $\begin{array}{c}\text { Somewhat } \\
\text { Agree }\end{array}$ & $\begin{array}{c}\text { Strongly } \\
\text { Agree }\end{array}$ & $\begin{array}{l}\text { No Answer } \\
\text { from } \\
\text { Respondent }\end{array}$ \\
\hline $\begin{array}{l}\text { I have problems with } \\
\text { the research process } \\
\text { when I have to narrow } \\
\text { down a topic and } \\
\text { make it manageable }\end{array}$ & & & & & & \\
\hline $\begin{array}{l}\text { I have problems } \\
\text { with the research } \\
\text { process when I need } \\
\text { to evaluate what } \\
\text { constitutes a credible } \\
\text { resource for a given } \\
\text { assignment }\end{array}$ & & & & & & \\
\hline $\begin{array}{l}\text { I have problems with } \\
\text { the research process } \\
\text { when I become } \\
\text { overwhelmed by all } \\
\text { the information that is } \\
\text { out there }\end{array}$ & & & & & & \\
\hline $\begin{array}{l}\text { I have problems with } \\
\text { the research process } \\
\text { when I have to figure } \\
\text { out how to avoid } \\
\text { plagiarizing in my } \\
\text { paper }\end{array}$ & & & & & & \\
\hline $\begin{array}{l}\text { I have problems with } \\
\text { the research process } \\
\text { when I have to } \\
\text { figure out what each } \\
\text { professor wants in } \\
\text { his or her particular } \\
\text { assignment }\end{array}$ & & & & & & \\
\hline $\begin{array}{l}\text { I have problems with } \\
\text { the research process } \\
\text { when I try to find } \\
\text { resources using the } \\
\text { SMC library Web site }\end{array}$ & & & & & & \\
\hline $\begin{array}{l}\text { I have problems } \\
\text { with the research } \\
\text { process when I } \\
\text { have to conform } \\
\text { to the professor's } \\
\text { perspective, instead } \\
\text { of my expressing my } \\
\text { own perspective }\end{array}$ & & & & & & \\
\hline
\end{tabular}




\begin{tabular}{|l|l|l|l|l|l|l|}
\hline & $\begin{array}{c}\text { Strongly } \\
\text { Disagree }\end{array}$ & $\begin{array}{c}\text { Somewhat } \\
\text { Disagree }\end{array}$ & $\begin{array}{c}\text { Neither } \\
\text { Agree } \\
\text { nor } \\
\text { Disagree }\end{array}$ & $\begin{array}{c}\text { Somewhat } \\
\text { Agree }\end{array}$ & $\begin{array}{c}\text { Strongly } \\
\text { Agree }\end{array}$ & $\begin{array}{c}\text { No Answer } \\
\text { from } \\
\text { Respondent }\end{array}$ \\
\hline $\begin{array}{l}\text { I have problems with } \\
\text { the research process } \\
\text { when I have to write } \\
\text { the actual paper }\end{array}$ & & & & & & \\
\hline $\begin{array}{l}\text { I have problems } \\
\text { with the research } \\
\text { process when I have } \\
\text { to overcome my } \\
\text { own anxiety with the } \\
\text { research process }\end{array}$ & & & & & & \\
\hline
\end{tabular}

13. On the average, how much time do you allocate for researching and collecting resources for a 4-6-page research paper for a Humanities or Social Sciences class? (Please choose one answer only.)

Under 1 hour

$\square$ 1-2 hours

3-5 hours

6-9 hours

$\square$ More than 9 hours

14. On the average, how much time do you allocate for writing and editing a 4-6-page research paper for a Humanities or Social Sciences class? (Please choose one answer only.)

$\square$ Under 1 hour

1-2 hours

3-5 hours

6-9 hours

More than 9 hours

15. What one-thing matters to you the most when you are working on a 4-6-page research paper for a Humanities or Social Sciences class? (Please choose one answer only.)

$\square$ The grade I get from the professor.

$\square$ Getting the assignment finished

$\square$ Learning something new

$\square$ Being creative with an assignment

$\square$ Finding the best research resources I can

Improving my research skills

$\square$ No answer from respondent

If other, please specify: 


\section{Notes}

1. This definition of information literacy is a compilation, derived from definitions provided by different campus libraries and published online. Available online from www.google.com/ search?hl=en\&client=firefoxa\&rls=org. mozilla:enUS:official\&hs=1P3\&pwst=1\&defl=en\&q=define: Information+Literacy\&sa=X\&oi=glossary_definition\&ct=title. [Accessed 24 April 2007].

2. For more about the complexities with defining information literacy, see David Bawden, "Information and Digital Literacies: A Review of Concepts," Journal of Documentation 57 (Mar. 2001): 218-59.

3. For one of the few studies published in the library literature about students' research practices, see the qualitative study by Gloria J. Leckie, "Desperately Seeking Citations: Uncovering Faculty Assumptions about the Undergraduate Research Process," Journal of Academic Librarianship, 22 (May 1996): 201-08.

4. Another article by the same author, discussing findings from this research, appeared in First Monday and was entitled "Beyond Google: How Do Students Conduct Academic Research?" by Alison J. Head, First Monday 12, no. 8 (Aug. 2007) and is available online from http://firstmonday. org/issues/issue12_8/head/index.html. [Accessed 25 October 2007] and a First Monday Podcast entitled, "Google Scholars?," an interview with Alison Head (Feb. 2008), http://www.firstmondaypodcast.org/audio/head_final.mp3, (5.3 MB, 15:22). [Accessed 21 July 2008].

5. The complete report issued from this study, including research tools, is available online from http://library.stmarys-ca.edu/features/SMCInfoLit.pdf (400 KB). [Accessed 6 July 2007].

6. Ibid.

7. A definition of information literacy was first issued by ACRL in 1989. In 2000, ACRL published "Information Literacy Competency Standards for Higher Education," ACRL Standards Committee (2000), in which they laid out standards, performance indicators, and outcome measures and referred to their own 1989 definition, while expanding its meaning at the same time. Available online from http://www.ala.org/ala/acrl/acrlstandards/standards.pdf. [Accessed 26 June 2007].

8. Ibid.

9. Ibid., 2 .

10. Ibid., 3 .

11. Ibid., 4.

12. The statistic, 13 percent, which described information literacy rates from the ETS study, appeared in an article about the ETS study by Andrea L. Foster, "Students Lack 'Information Literacy' Testing Service Finds," Chronicle of Higher Education, Oct. 17, 2006. For preliminary results from the study, see Educational Testing Services, 2006 ICT Literacy Assessment Preliminary Findings (2007). Available online from www.ets.org/Media/Products/ICT_Literacy/pdf/2006_Preliminary_Findings.pdf. [Accessed 26 June 2007].

13. In Kathleen Dunn's large-scale quantitative 2002 study of students enrolled in the California State University System, she found information literacy levels are strongly correlated with library use. The finding was published in "Assessing Information Literacy Skills in the California State University: A Progress Report," Journal of Academic Librarianship, 28, no. 1-2 (Jan.-Mar. 2002): 26-35.

14. Steve Jones, "The Internet Goes to College: How Students Are Living in the Future with Today's Technology," Pew Internet and American Life Project, (Sep. 2002). Available online from www.pewinternet.org/pdfs/PIP_College_Report.pdf. [Accessed 27 June 2007].

15. See Anna M. Van Scoyoc, "The Electronic Academic Library: Undergraduate Research Behavior in a Library without Books," Libraries and the Academy 6 (Jan. 2006): 47-58; and Deborah J. Grimes and Carl H. Boening, "Worries with the Web: A Look at Student Use of Web Resources," College \& Research Libraries 62, no. 4 (2005): 11-23. Grimes' article available online from www.ala. org/ala/acrl/acrlpubs/crljournal/backissues2001b/january01/grimes.pdf. [Accessed 28 June 2007].

16. Christen Thompson, "Information Illiterate or Lazy: How College Students Use the Web for Research," Libraries and the Academy 3, no. 2 (Apr.) 259-68.

17. Angela Weiler, "Information-Seeking Behavior in Generation Y Students: Motivation, Critical Thinking, and Learning Theory," Journal of Academic Librarianship 31, no. 1 (Jan. 2005): 46-53.

18. Anne F. Pierce, "Improving the Strategies High School Students Use to Conduct Research on the Internet by Teaching Essential Skills and Providing Practical Skills," ED 427756 (1998).

19. Ibid.

20. Leckie, "Desperately Seeking Citations," 203.

21. Ibid.

22. Ibid.

23. Christopher Hollister, "Having Something to Say," Communications in Information Literacy 1, no. 1 (2007). Available online from www.comminfolit.org/index.php/cil/article/view/ Spring2007ED1/24. [Accessed 27 June 2007]. 
24. Saint Mary's College Fact Book (2007). Available online from www.stmarys-ca.edu/about/ fact_book/toc.html. [Accessed 24 June 2007].

25. The sample is fairly representative of gender of the overall student population on campus. Current statistics from the SMC Fact Book show the SMC population is 65 percent female and 35 percent male.

26. Kimberly A. Neuendorf, The Content Analysis Guidebook (Thousand Oaks, Calif.: Sage, 2002), 151. Also see Klaus Krippendorf, Content Analysis: An Introduction to its Methodology (Thousand Oaks, Calif.: Sage, 1980): 134.

27. Neuendorf, The Content Analysis Guidebook, 143.

28. Note that students in the survey $(40 \%)$ reported turning to course readings first for academic research. Although professors and librarians may define course-related research as identifying, evaluating, and using "outside references," our student sample considered class readings a logical first step in their research process, especially as they tried to narrow down a topic and determine the scope of their papers.

29. The data reporting students' limitations was derived from Survey Question \#12, which used a five-point Likert scale (that is, a statement that asks the respondents to rank their level of agreement to disagreement with the statement). The percentages reported in this section combine the percentages and collapse two response categories: those who "strongly agreed" and "somewhat agreed" with statements about what worked for them when they conducted research and what challenges they faced.

30. Note that our content analysis was of research handouts professors have distributed in SMC classes over the last two years. We did not collect or analyze data about the information and explanations professors may verbally provide to students in class or in office hours about research assignments and how to conduct research.

31. ALA Standards for Higher Education, 11.

32. ALA Standards for Higher Education, 8.

33. For more about the structures and purposes of rubrics, as well as their strengths and weaknesses, see Heidi Goodrich Andrade, "Teaching with Rubrics: The Good, the Bad, and the Ugly," College Teaching 53, no. 1 (Winter 2005), 27-31.

\title{
University of the West Indies Press

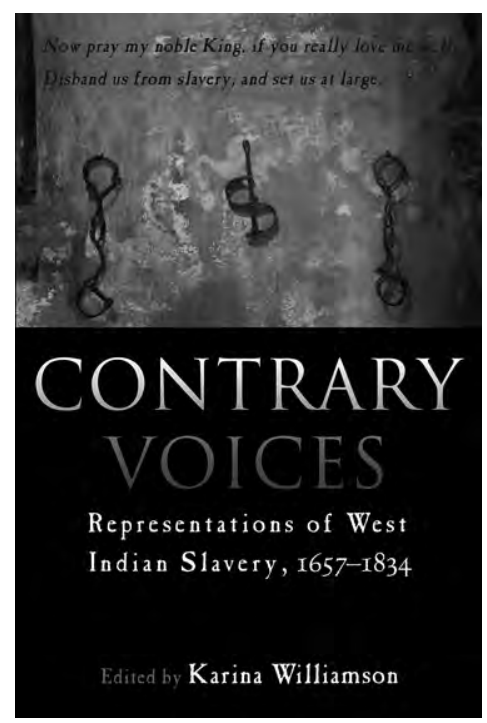

\section{Contrary Voices}

Representations of West Indian Slavery

Karina Williamson (ed.)

2008

ISBN 978-976-640-208-2

$531 \mathrm{pp} 6 \times 9$

US\$30 (s) Paper

\author{
For orders and customer service in the United \\ States, contact Longleaf Services, Inc. \\ Customer Service \\ Longleaf Services, Inc. \\ P.O. Box 8895 \\ Chapel Hill, NC 27515-8895 \\ Tel: (800) 848-6224; Fax: (800) 272-6817 \\ Email: customerservice@longleafservices.org \\ San Number: 203-3151
}




\section{e New Palgraye Dictionary of Econom}

\section{Second Edition}

Edited by Steven N. Durlauf and Lawrence E. Blume

for the first edition:

ispensable reference tool for both junior and senior scholars in economi

-Kenneth J. Arrow, Nobel Prize-winner in Economics

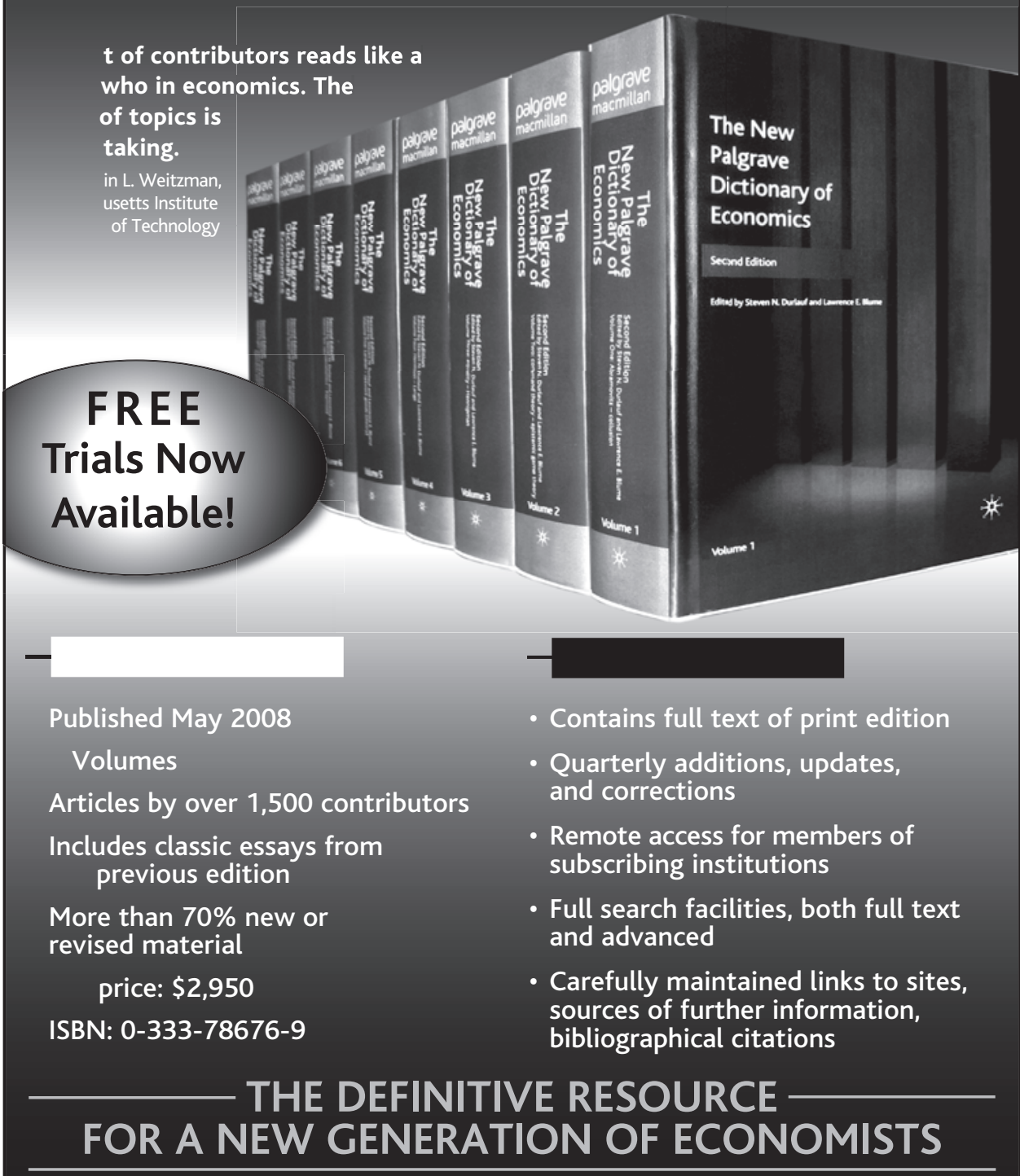

Request your free 30-day online trial today! FOR PRICING \& TRIALS: Onlinesales@palgrave-usa.com 